

\title{
From Policy to Pedagogy: The Implications of Sustainability Policy for Sustainability Pedagogy in Higher Education
}

\author{
Nora Timmerman \\ Amy Scott Metcalfe \\ University of British Columbia
}

\begin{abstract}
In response to the growing number of sustainability policies being enacted at higher education institutions, this article examines the relationship between policy and pedagogy, asking how policy texts can both enable and impede the implementation of sustainability pedagogy in higher education. To explore this question, we have undertaken a case study at the University of British Columbia, analyzing two campus-wide visionary policies that call for sustainability education: Trek 2010: A Global Journey and Inspirations and Aspirations: The Sustainability Strategy. We analyze these documents to show how the goals and strategies within them have the potential to affect the teaching and learning of sustainability across the university, directly and indirectly. Our analysis is coupled with a series of suggestions on how the policy process might be better executed in the future for more pedagogically effective sustainability policy.
\end{abstract}

\section{RÉSUMÉ}

Dans un contexte d'augmentation significative des politiques de durabilité dans les institutions d'enseignement supérieur, cet article cherche à déterminer dans quelle mesure le contenu de ces politiques favorise ou nuit à la mise en oeuvre d'une pédagogie de la durabilité en milieu universitaire. En guise d'étude de cas, nous avons entrepris 
l'analyse de deux politiques de durabilité à l'Université de la ColombieBritannique : "Trek 2010 : A Global Journey " et " Inspirations and Aspirations : The Sustainability Strategy ". Nous souhaitons démontrer comment les objectifs et les stratégies stipulés dans ce type de politiques peuvent influencer, directement ou indirectement, l'enseignement et l'apprentissage de la durabilité en milieu universitaire. Nous avons également inclus une série de suggestions visant à améliorer les processus d'élaboration des politiques de durabilité afin d'en assurer, à l'avenir, un meilleur arrimage au plan pédagogique.

\section{INTRODUCTION}

Higher education institutions are complex organizations with legacies of policies, practices, and personnel that carry over from one academic administration to another. Emerging within the last two decades is a new generation of university-wide policies that target sustainability as a goal (Wright, 2002). Acknowledging their attributes, Filho (1999) wrote, "University-wide sustainability policies have the ... [potential to facilitate] the ways sustainability measures are implemented, ... [to provide] guidance in relation to the priority areas, ... [and to] facilitate a dialogue between all of those who have a stake in the area" (p. 27). Yet policy-makers must proceed with caution, as at times policy instruments are in conflict, contain gaps, or are not coherent, creating confusion and barriers to implementation. For many universities this has been true for sustainability policies, as even signatories to international declarations have been unable to create clear strategies or actions toward the institutionalization of sustainable practices (Wright, 2002).

Although universities have often had success in implementing sustainability policies in the area of operations (e.g., building codes and energy usage), implementation has proved to be much more difficult in the processes of teaching and learning (i.e., pedagogy). Identifying this troublesome gap in an in-depth case study, Moore (2005a, 2005b) researched the ways in which a large, research-intensive Canadian university, the University of British Columbia (UBC), undertook the challenge of sustainability education after having signed and/or created a number of sustainability policies. In an effort to further understand the relationship between university-wide sustainability policy and pedagogy, we have built upon Moore's study and offer an extended analysis of UBC as a site of contested policies and practices in relation to sustainability pedagogy. Focusing on the language and implications of two of UBC's major sustainability policies, this present case study is intended to serve as, 1) an in-depth description and demonstration of the policies undertaken by a large-scale university striving for sustainability; 2) an illustration of some of the frequent pitfalls to which institutional-level policies are susceptible; and 3) a continuation of the scholarly dialogue surrounding policy processes, which may result in more effective policies and subsequently stronger sustainability pedagogy in higher education. 
In line with these intentions, we begin with a look at the context of this case study. We discuss UBC's history with sustainability pedagogy, examine the ground covered previously by Moore's (2005a, 2005b) case study, and set out our particular analysis of UBC's mission-level policies: Trek 2010: A Global Journey (UBC, Office of the President, 2005) and Inspirations and Aspirations: The Sustainability Strategy (UBC Sustainability Office, 2006). This is followed by a brief summary of the theoretical framework we used to analyze these two texts. Next, after discussing the content of the policies as it relates to the direct and indirect implications for pedagogy at UBC, we offer a constructive critique, identifying the gaps and potentially detrimental implications found within the content. Finally, we outline recommendations that identify processes by which administrators and instructors can create goals and implementation strategies for sustainability education.

\section{Context: The University of British Columbia}

In "Policy, Priorities and Action: A Case Study of the University of British Columbia's Engagement with Sustainability," Moore (2005b) discussed the creation of a 1997 policy document, the UBC Sustainable Development Policy. In her study, which included document analysis, participant observation, and interviews of key stakeholders involved in the policy process, she examined the social construction of sustainability policy in the context of this large research university, a signatory of the most recognized international agreement for sustainability in higher education, the 1990 Talloires Declaration. By many measures, UBC was then and still is a leader in sustainability policy in higher education. ${ }^{1}$ Furthermore, UBC has become a locus of research excellence in the area of sustainability, with units such as the Design Centre for Sustainability, the Centre for Interactive Research and Sustainability, and the Centre for Sustainability and Social Innovation. However, good policy-making does not necessarily lead to good policy implementation, even when the policy in question concerns a key area of institutional inquiry. Accordingly, Moore (2005b) concluded her article with a simple, yet challenging, question: "Can a university learn to walk its own talk?" (p. 196).

In her review of sustainability policy and education at UBC, Moore (2005a) noted that, in general, "the current trajectory of university education is not integrated with the ideas, values and processes connected to the concept of sustainability" (p. 553). She concluded that, despite UBC's demonstrated commitment to sustainability as a concept and its achievements in green design and operations, several barriers (disciplinarity, competition, misdirected evaluation, and unclear priorities) inhibited the institution from fully realizing its educational goals.

The same year that Moore's case study (2005b) was published, UBC released the campus-wide visionary report Trek 2010: A Global Journey, and the following year, it released a second report, Inspirations and Aspirations: The Sustainability Strategy. Both documents are "policy texts" (Scott, 2000), in that they 
are intended to shape and guide UBC's current policy agenda and are legacies of its 1997 Sustainable Development Policy. In the words of former UBC president Martha Piper, "Trek 2010 articulates the goals we have set for ourselves in order to carry out [our] responsibility, and the strategies by means of which we hope to succeed" (UBC, Office of the President, 2005, p. 3); building on the material presented in Trek 2010, the Sustainability Strategy is the "wide-ranging plan for the realization of the vision presented in Trek 2010" (p. 1). Together, these two policy documents presented the official vision of UBC's upper administration in terms of the institutional goals for the sustainable operation of the university, and the teaching and learning occurring within it.

Although Trek 2010 and the Sustainability Strategy were not specifically created in response to the barriers that Moore identified in her research, their stated goals have the potential to address her concerns. In order to investigate this potential, we extended Moore's case study and focused our analysis on the pedagogical implications of these documents, employing a policy discourse analysis to more closely examine the ways in which policy texts can both enable and impede the implementation of sustainability pedagogy in higher education. Thus, a decade after the creation of UBC's Sustainable Development Policy, we asked, "How does the University plan to walk its own talk?"

\section{Theoretical Framework}

A number of perspectives informed our reading, interpretation, analysis, and representation of Trek 2010 and the Sustainability Strategy. Our first step was to clarify our understanding and use of the term "sustainability." Commonly held understandings of sustainability in education refer to the "three pillars" or the "three-legged stool" of sustainability, suggesting that it must tie together socially just interactions and relationships, economically responsible behaviour, and environmental vitality (Corcoran, 2004; Furman \& Gruenewald, 2004; Raskin et al., 2002). Although these three foci-society, economy, and environment-are specifically referenced several times in Trek 2010 and the Sustainability Strategy, we recognize that they are not easily integrated at the level of institutional policy. As Brandt (2004) stated,

"sustainability" as used by economists (e.g., sustained growth and consumption) is often directly opposed to ecological sustainability (e.g., sustained living systems). Scientific, political, and symbolic meanings of sustainability are often used interchangeably with conflicting messages-and consequently, sustainability lacks meaning in these contexts. (p. 97)

Particularly in post-secondary institutions, where people in various disciplines (e.g., economics, environmental studies, women's studies) shape and are responsible for policies, it becomes necessary to move beyond a conceptual consideration of the three pillars to an ethically grounded vision. That is, a defi- 
nition or understanding of sustainability must also specify how and to what end economic, environmental, and social concerns are identified and addressed.

As such, we appreciate Fritjof Capra's (1999) suggestion that "a sustainable community is designed in such a way that its ways of life, businesses, economy, physical structures, and technologies do not interfere with nature's inherent ability to sustain life" (p. 1). Because this understanding of sustainability ties any economic, social, or environmental concern not only to the sustenance of human life but to all life, it reaches beyond the three-pillar approach by acknowledging the existence of, and demanding respect for, the natural world in and of itself. This perspective on sustainability informed our approach, interpretation, analysis, and discussion of the Trek 2010 and Sustainability Strategy documents.

A holistic understanding of pedagogy (Miller, 1988) also informed our analysis. In post-secondary education contexts, the processes of teaching and learning occur at multiple complex levels; for instance, as well as learning the knowledge addressed by the instructor and outlined by course curricula, students learn lessons from what has been omitted from the course content (Margolis, 2001). Furthermore, the setting in which learning takes place-the arrangement of tables and chairs, the overall campus environment (Strange \& Banning, 2001; Temple, 2008), and the administrative, organizational structures that govern higher education institutions-are significant pedagogical influences.

Other aspects of our analysis and discussion were drawn from McLean's (2006) application of Habermasian social critique to the topic of university pedagogy; this application reveals the potential of the university to serve not only as a site of research and development (with political and economic relevance) but also as a transformative social space for civil engagement. Higher learning, therefore, can be a transgressive and socially constructing act. With this in mind, our understanding of "pedagogy" is comprised of the content of a particular curriculum or learning opportunity, the wider organizational and environmental context of that learning, and the constituencies involved in the learning and its outcomes. Thus, in considering sustainability pedagogy in higher education, instructors, students, and academic administrators must consider the content, contexts, and constituencies involved in learning about sustainability.

Finally, we placed ourselves within an expanding body of work known as "critical policy analysis" (Fischer, 2003; Orsini \& Smith, 2007; Taylor, 1997), which applies critical and social theory to the policy process. For the purposes of this article, we used this position to consider the university both as a policy arena at the institutional level and as a key instrument in the public policy process and the creation of a (more) civil society. The university informs public policy through research output in fields such as political science, sociology, medicine, law, and education; in addition, the university is implicated (for better or for worse) in shaping the values and practices of the current and future citizenry-those who enrol as students and those who do not. In this way, university policy and policy-making can be understood as part of the larger policy environment and as a potential site of social change. 


\section{METHODS OF ANALYSIS}

Both Trek 2010 and the Sustainability Strategy have widespread institutional influence as policy documents; for example, they serve as guidelines for future policy decisions, set expectations internally and externally for UBC's operations, inspire professors in their teaching and research, and draw students to the university. Of particular interest to us was the potential of these policy texts to influence sustainability pedagogy at UBC. At the same time, we recognize that not all learning in post-secondary contexts is formal; indeed, Beringer and Adomßent (2008) discussed the importance of informal learning environments to the success of campus sustainability initiatives. Therefore, we have classified the pedagogical implications of sustainability policy into two categories: direct and indirect. Direct pedagogy, which primarily involves faculty and students, refers to curricular content, teaching/learning practices, and new programs and courses. Indirect pedagogy refers to broad-based learning that is not necessarily reflected in explicit curricular content, such as the learning environments of classrooms and laboratories, external community contexts, professional development programs for faculty, and informal learning opportunities such as administrators and support staff. With these distinctions in mind, our primary research question was, "Do the two policy texts provide an adequate shared vision to guide the formation of a campus-wide sustainability pedagogy, both directly and indirectly?"

To answer this question, we systematically reviewed the two policy texts and identified any references to pedagogy (both direct and indirect) within them. We then analyzed the texts by organizing passages into various categories to determine the specific strategies that exist within these documents and their intended implications. A detailed account of each category, supplemented with examples from each text, is provided below, accompanied by a summary of the results of our analysis, which are shown in full detail in Table 1 and Table 2.

Table 1 focuses on the goals and strategies found in Trek 2010 and the Sustainability Strategy that have direct implications for pedagogy. In the sense that direct pedagogy is understood as curriculum content and teaching practice, the goals and strategies identified as direct contain suggestions aimed at curriculum planners and/or instructors. For example, Trek 2010 suggests, "Integrate global perspectives into curricular planning and teaching practice" (p. 11). Table 2 summarizes the goals and strategies in the two policy texts that have indirect implications for pedagogy. Although those identified as having indirect implications could affect classroom instruction and/or curriculum if implemented, in general, they are more concerned with broader pedagogical interests. For example, the Sustainability Strategy document includes this suggestion: "Create community-university groups to identify possible areas for joint activity in such areas as local health and education needs" (p. 7).

After coding all of the pedagogically related goals and strategies in the two texts as either direct or indirect, we further sorted them into emergent and recurring themes. The themes represent the various categories of goals and 
strategies found in both documents and were differentiated in terms of their application or intended audience. For example, many of the indirect goals and strategies involve the university's aspirations for graduating students to have gained certain skills and knowledge during their time in school. Thus, the theme "Qualities of Graduates from UBC" was created to describe this set of goals and strategies and, as such, can be considered as a "socializing" or "citizenbuilding" theme. These themes are listed in the far left column of each table. Finally, paraphrased versions of the actual pedagogical goals and strategies found within Trek 2010 and the Sustainability Strategy are listed to the right of the corresponding theme and under their appropriate column, sorted according to policy text. Each goal or strategy is followed by a number in parentheses, which indicates how many times that particular goal or strategy appeared in its respective policy text.

Recognizing the importance of specificity when dealing with terms such as "sustainability" or "global citizenship," we have ensured that each of the paraphrased goals and strategies in the tables shares much of the same verbiage, sentence structure, and scalar properties as the originals from which they were taken. That is, we have represented the literal goals and strategies noted in Trek 2010 and the Sustainability Strategy as accurately as possible, using the same words, flow, and generalizability exhibited in the original documents.

\section{FINDINGS AND DISCUSSION}

Before a change can be made in any situation, the need for change must be acknowledged. For this reason, we applaud the initiators and authors of Trek 2010 and the Sustainability Strategy for bringing their concerns to the table in a constructive way and subsequently creating these two visionary documents. However, as with all policy texts, there is room for improvement. To that end, based on our analysis, we offer four major findings and some critiques on the pedagogical implications of the goals and strategies identified (and unidentified) in these two documents.

First, the goals and strategies related to pedagogy are predominantly general and therefore difficult to incorporate into a curriculum or an academic management plan. Compared to the mechanistic goals identified in the Ecological Targets section of the Sustainability Strategy, such as "Reduce steam plant NOx emissions by $80 \%$ from 2000 levels" (p. 24), the goals and strategies regarding pedagogy are much harder to clearly understand, implement, and/or assess. For example, Trek 2010 asks faculties at UBC to facilitate "the augmentation of existing courses ... [to] ensure that all students develop a greater awareness of their responsibilities as global citizens" (p. 11). And yet, although such a strategy may sound clear on paper, implementing it can lead to many questions: Which faculties are responsible-all, most, or just a few? Are all courses within the faculty, at both the undergraduate and graduate levels, intended to be augmented? Do the instructors of each course decide how the course will change, or is the change created at the faculty level and then passed down, or 
Table 1

Direct Implications for Pedagogy

\begin{tabular}{|c|c|c|}
\hline Themes & Trek 2010 & Sustainability Strategy \\
\hline \multirow[t]{2}{*}{ Curriculum } & $\begin{array}{l}\text { Understanding and teaching } \\
\text { about social, economic, and } \\
\text { ecological sustainability (1) }\end{array}$ & $\begin{array}{l}\text { Understanding and teaching about } \\
\text { social, economic, and ecological } \\
\text { sustainability (4) }\end{array}$ \\
\hline & $\begin{array}{l}\text { Understanding and teaching } \\
\text { about global citizenship and } \\
\text { global issues (5) }\end{array}$ & \\
\hline \multirow[t]{4}{*}{ Ways of Learning } & $\begin{array}{l}\text { Increase community service } \\
\text { learning opportunities and } \\
\text { participation (2) }\end{array}$ & $\begin{array}{l}\text { Increase community service learn- } \\
\text { ing opportunities and participa- } \\
\text { tion (2) }\end{array}$ \\
\hline & $\begin{array}{l}\text { Increase research-based learn- } \\
\text { ing, experiential learning, } \\
\text { co-operative education, and } \\
\text { problem-based learning (3) }\end{array}$ & \\
\hline & $\begin{array}{l}\text { Increase clinical educational } \\
\text { opportunities (1) }\end{array}$ & \\
\hline & $\begin{array}{l}\text { Increase quality and use of } \\
\text { technology in teaching (1) }\end{array}$ & \\
\hline
\end{tabular}

New Academic Courses Increase lifelong and distance and Programs learning programs (4)

Increase programs and courses on sustainability and global citizenship (3)

New sustainability-focused programs (1)

Increased community service learning courses and programs (3)

Increased courses, programs, and enrolment on Aboriginal issues (3)

Increased courses, programs, and

Increased courses, offerings, and enrolment in mobility and international programs (3) enrolment on Aboriginal issues (2)

Recognize interdisciplinarity as an important part of academic planning (2)

do instructors and administrators work together to ensure that courses meet the target? How is student "awareness" to be assessed? Neither Trek 2010 nor the Sustainability Strategy provides this much detail. However, if UBC is truly interested in accountability (which appears as another theme throughout the documents), the pedagogical strategies and goals identified in these policy texts require a much higher level of specificity.

It may be that this lack of specificity is linked to jurisdiction, in particular, not overstepping the jurisdiction of individual faculties and departments, which hold great power when it comes to curricular matters. Indeed, while the docu- 
Table 2

Indirect Implications for Pedagogy

\begin{tabular}{|c|c|c|}
\hline Themes & Trek 2010 & Sustainability Strategy \\
\hline \multirow[t]{3}{*}{$\begin{array}{l}\text { Campus Com- } \\
\text { munity }\end{array}$} & “Best” university practices (1) & $\begin{array}{l}\text { Asking faculty, staff, and } \\
\text { students to incorporate and } \\
\text { understand sustainability ( } 2 \text { ) }\end{array}$ \\
\hline & & $\begin{array}{l}\text { Increase connections with the } \\
\text { Aboriginal community and work } \\
\text { to meet their learning needs (2) }\end{array}$ \\
\hline & & Health and wellness (1) \\
\hline \multirow[t]{4}{*}{$\begin{array}{l}\text { Qualities of } \\
\text { Graduates from } \\
\text { UBC }\end{array}$} & $\begin{array}{l}\text { Graduates have learned analytical, } \\
\text { problem-solving, critical thinking, } \\
\text { and communication skills (4) }\end{array}$ & $\begin{array}{l}\text { Graduates have learned to be } \\
\text { leaders (1) }\end{array}$ \\
\hline & $\begin{array}{l}\text { Graduates have learned to be global } \\
\text { citizens (2) }\end{array}$ & $\begin{array}{l}\text { Graduates have learned to be } \\
\text { global citizens (1) }\end{array}$ \\
\hline & $\begin{array}{l}\text { Graduates have learned to be innova- } \\
\text { tive and creative ( } 2 \text { ) }\end{array}$ & \\
\hline & $\begin{array}{l}\text { Graduates will be responsible and } \\
\text { work for positive social change within } \\
\text { communities (1) }\end{array}$ & \\
\hline \multirow{4}{*}{$\begin{array}{l}\text { Teacher Recogni- } \\
\text { tion, Training, and } \\
\text { Standards }\end{array}$} & $\begin{array}{l}\text { Students have learning exchanges } \\
\text { with senior faculty members (1) }\end{array}$ & \\
\hline & Teacher training (2) & \\
\hline & $\begin{array}{l}\text { High teaching standards incorporat- } \\
\text { ing sustainability outcomes (2) }\end{array}$ & \\
\hline & $\begin{array}{l}\text { Recognition of outstanding teaching } \\
\text { and community engagement (3) }\end{array}$ & \\
\hline \multirow[t]{3}{*}{$\begin{array}{l}\text { Resources and } \\
\text { Facilities }\end{array}$} & $\begin{array}{l}\text { "Best" resources for learning and } \\
\text { research, including new facilities (3) }\end{array}$ & $\begin{array}{l}\text { Encourage efficient use of space, } \\
\text { energy, and water in existing } \\
\text { and new buildings (10) }\end{array}$ \\
\hline & Improved technology and support (2) & \\
\hline & Class size (enrolment) (2) & \\
\hline Partnerships & $\begin{array}{l}\text { Create student-alumni learning part- } \\
\text { nerships (1) }\end{array}$ & $\begin{array}{l}\text { Create community-university } \\
\text { connections (2) }\end{array}$ \\
\hline
\end{tabular}

ments address the content and contexts of sustainability pedagogy, little reference is made to the constituencies involved in implementing these goals. In addition, the content of sustainability in curricular terms may be caught between disciplinary and interdisciplinary boundaries-on the one hand, belonging to all fields and, on the other hand, researched and taught in particular ways according to prevailing disciplinary norms and epistemologies. It has been argued that sustainability necessitates interdisciplinary perspectives (Tappeiner, Tappeiner, \& Walde, 2007), but successful institutional structures for interdisciplinary research and teaching are rare (Ferrer-Balas et al., 2008). This is especially significant in that society's conceptions about sustainability are yet to be fully 
formed, and the transfer from research to teaching plays an important role in shaping our understanding of what is meant by the term and its potential for bringing about effective social change.

Second, loose and ambiguous language is used throughout the two reports, beyond that found in the goals themselves. Specifically, and perhaps most importantly, the terms "global citizenship" and "sustainability" are left undefined, despite appearing on virtually every page and despite having a history of different meanings for different people at UBC and beyond. Thus, global citizenship and sustainability are not only ambiguous and contested terms in and of themselves, but are also core concepts within UBC's vision and thus ought to be defined (or at least thoroughly described) upfront in both policy texts. These definitions would help students, teachers, and administrators understand, implement, and assess the efficacy of the goals and strategies outlined in Trek 2010 and the Sustainability Strategy; without these definitions, those in charge of implementing the goals and strategies may be subject to misunderstandings, contradictions, and apathy. Although providing a comprehensive definition for either term is difficult, the failure to offer a context for shared meaning-making closes the door on opportunities for debates that can serve as excellent learning processes by encouraging continual improvement and refinement of our understandings and strategies. Moreover, since sustainability (at least as we understand it) can be considered a global imperative, presumably being a global citizen has implications for one's perspective on sustainability. Harmonization of these definitions could be a critical move toward goal achievement on both fronts.

Third, there is a serious lack of direction and visioning for university teachers and academic administrators when it comes to incorporating sustainability directly into courses and curricula. Although the term "sustainability" is often accompanied by references to society, environment, and economy in the two documents, a description of how, why, or for what purpose these three concepts are tied together is missing. Of the pedagogically related goals and strategies found in these texts, few speak directly either to the types of things students should learn in the classroom or to the types of learning that are most conducive to a sustainable academic environment. Instead, more emphasis has been placed on campus resources and facilities and on the characteristics that UBC wants to see instilled in its graduates, all of which have indirect pedagogical significance, while few goals are in place that have the potential to directly inform and guide teacher-student interaction. This may be an area where the authors of these documents chose not to go into detail in order to leave the specific curricular objectives up to individual faculties and departments. However, should this be the case, the lack of a campus-level vision that addresses curricula and classroom interaction works against the stated goal that sustainability be incorporated across all university curricula.

Fourth, the Sustainability Strategy document follows through on few of the pedagogical goals and strategies identified in the original Trek 2010 document. The small amount of overlap between the items in columns two and three 
in Tables 1 and 2 illustrate this point. The gaps between Trek 2010 and the Sustainability Strategy reveal a great deal of room for improvement; they are highlighted here as a starting point borne out of hopeful inquiry and toward a process of re-invention. Policy recommendations that may address some of these concerns are outlined in the next section.

\section{Policy Recommendations}

Although both of the policy texts analyzed in this study claim to have incorporated a public-engagement process, we recommend that more and different types of engagement be explored in future policies and revisions. To this end, we recommend that UBC's President's Office and Sustainability Office specifically target current students, ongoing research projects, academic administrators, and community organizations to learn about and create visionary, practical, and up-to-date goals and strategies around future pedagogical practice at the university.

One of the primary outcomes of this engagement process should be a supplementary policy document designed to integrate Trek 2010 and the Sustainability Strategy for the specific purpose of providing input into how UBC will make space for sustainability pedagogy. Laforest and Phillips (2007) have written about a number of emerging tools aimed at creating "citizen engagement" in the policy process (p. 67), and these tools might be useful for expanding the pedagogical vision of the two documents into more specific targets unique to the UBC community. Laforest and Phillips suggest the use of

citizen assemblies, the "citizen jury," and deliberative polling. All of these techniques bring small groups of randomly selected citizens together to address a policy problem, give them background information and access to experts who may be called upon as needed, and provide space and time to discuss and debate various solutions. At the end of the process, it is normally expected that a consensus position be reached. (p. 72)

Although the policy process at higher education institutions differs from the municipal, provincial, or federal process, it is still viable to think of students, teachers, and staff as "citizens" of the university, each with some responsibility to engage in ongoing affairs. Thus, we encourage the President's Office and the Sustainability Office to consider using some of Laforest and Phillips's small group methods to bring UBC's "citizens" together to create more specific goals and strategies, definitions of "sustainability" and "global citizenship," and a systematic focus on pedagogy as part of UBC's long-term visioning.

Moore $(2005 \mathrm{a}, 2005 \mathrm{~b})$ noted that UBC policy-makers had worked with a select few of the larger on-campus groups and organizations that were focusing on sustainability pedagogy and research. Given that the basis of Moore's case study, the 1997 Sustainable Development Policy, is now more than a decade 
old, and that the current Trek 2010 policy and the Sustainability Strategy are seen throughout the UBC campus as key planning documents, a reassessment of policy participants is in order. Yet, the level of staff, faculty, and student involvement in the development of sustainability concepts and content suggests that it may be better to consider these individuals as key policy actors rather than mere stakeholders. For example, students and faculty in our own Faculty of Education have formed an Eco/Environmental Education Caucus to better understand global citizenship and sustainability, including how to incorporate these concepts into teaching practices. Additionally, the Centre for Teaching and Academic Growth, the Institute for Resources, Environment and Sustainability, and the UBC Farm focus on pedagogical goals and strategies akin to those found in Trek 2010 and the Sustainability Strategy. These are all invaluable in-house resources for institutional policy development and enactment, and a close examination of these and other initiatives across the university could serve to inform other post-secondary institutions about successful sustainability endeavours. Furthermore, UBC students, faculty, and staff have written multiple theses, articles, and books on the topic of sustainability. To what extent is this research utilized both locally and globally? What would it take to collect and synthesize this research for review by the institution and the broader higher education community?

By working with these individuals and groups, institutional policy-makers have the opportunity to better understand, implement, and assess the pedagogical goals and strategies identified in campus sustainability policies. As Moore (2005b) suggested, "discussions about sustainability ought to be integrated into the academic planning process so faculty, staff and students can begin to consider how sustainability will be integrated into all programs on campus" (p. 196). Policy processes that are inclusive and integrated in these ways are more sustainable in and of themselves; moreover, long-term institutional commitment to sustainability requires an iterative, reflective policy process and intergenerational effort, particularly between administrative staff, support personnel, faculty, students, and community members. As Freire (2003) noted, "Knowledge emerges only through invention and re-invention, through the restless, impatient, continuing, hopeful inquiry human beings pursue in the world, with the world, and with each other" (p. 72).

Finally, it is important to mention a new development in sustainability policy that has recently begun at UBC. It has the potential to addresse several of the concerns and suggestions we have made in this article and may set a good example (at least at this early stage) for other higher education institutions to follow in their effort to address sustainability and pedagogy at the level of campus policy. In April 2009, a working group was formed to create a Sustainability Academic Strategy (SAS) that will be tied to UBC's new Strategic Plan; the SAS is to specify how future research developments and academic planning at the university can and should incorporate sustainability. Comprised of administrators, faculty, and students, the working group has a mandate to 
foster new forms of sustainability learning and research, and associated collaboration and partnership between UBC personnel and the various communities within which UBC is located. It will create a process through which the university community can demonstrate our shared interest in working toward a sustainable future. (Robinson, 2009, para. 6)

In its effort to achieve this mandate, the working group is using several strategies for engaging UBC's "citizens," including town hall meetings, online discussions, question-of-the-week forums, and targeted meetings with students and faculty studying sustainability education. Additionally, the working group has already been much more specific in describing "sustainability" and what it means for a university to address it. ${ }^{2}$ Four themes guide this collaborative policy-development process: Agent of Change, Campus as a Living Learning Lab, Operations \& Administration, and Teach \& Learn. The first public draft of the SAS is due in the fall of 2009. We are encouraged by these recent events and hope that the completed SAS policy document will contain rigorous goals and strategies for sustainability pedagogy at UBC. Future research will be necessary to examine the implementation phase of the SAS, with careful attention to the findings noted in the policy analysis we conducted for this study.

\section{CONCLUSION}

We approached the Trek 2010 and Sustainability Strategy policy documents in search of their potential to affect the content, contexts, and constituencies of sustainability pedagogy at UBC. Within these documents, we found that the goals and strategies that have a direct impact on pedagogy focus on curriculum (e.g., course objectives regarding sustainability), ways of teaching (e.g., the use of community service learning), and new courses and programs. However, there were greater implications for indirect pedagogy, ranging from improved facilities and resources to community partnerships, which affect informal learning opportunities. Although Trek 2010 and the Sustainability Strategy are steps in the right direction, they have shortcomings: their goals and strategies are too general and thus potentially difficult to implement; the contained language is ambiguous and terms are left undefined; both lack an explicit focus on curricula and classroom interaction; and there are few areas of pedagogical overlap between them. UBC's current effort to create a Sustainability Academic Strategy has the potential to address some of these concerns by creating pedagogical goals that are clear, direct, and easy to implement and assess.

Not surprisingly, we have come to the conclusion that it is not easy to "walk the talk." Even when it comes to the lofty business of creating visionary policies, there is always room for improvement. Throughout our study, we made an effort to identify the potential for connection between policy and pedagogy; our analysis, discussion, and recommendations, though tied specifically to the context of UBC, are evidence of the systematic visioning and re-visioning that 
are necessary to create robust sustainability policies at a higher education institution. Over time, we hope to see the effects of sustainability policy-at UBC and elsewhere-in the lesson plans, the classroom settings, the community partnerships, the teacher-student relationships, and, ultimately, the minds and hearts of students and teachers everywhere.

\section{NOTES}

1 The Sustainable Endowments Institute's College Sustainability Report Card rated the University of British Columbia as an "Overall College Sustainability Leader" in its 2009 survey of North American institutions (Sustainable Endowments Institute, 2008).

2 The open letter to the University describing the terms of reference for the Sustainability Academic Strategy states:

While there are many different views of how best to define sustainability, most of them include a recognition that we must live within biophysical carrying capacity, we must provide systems of governance that propagate the values we want to live by and we must provide an adequate material standard of living for all. We see sustainability not as a prescribed set of outcomes, but as the emergent property of a societal conversation about what kind of world we want to live in, informed by some understanding of the ecological, social and economic consequences of different courses of action based on knowledge about possible outcomes and their consequences. (Robinson, 2009, para. 4)

\section{REFERENCES}

Beringer, A., \& Adomßent, M. (2008). Sustainable university research and development: Inspecting sustainability in higher education research. Environmental Education Research, 14(6), 607-623.

Brandt, C. B. (2004). A thirst for justice in the arid southwest: The role of epistemology and place in higher education. Educational Studies, 36(1), 93-107.

Capra, F. (1999). Ecoliteracy: The challenge for education in the next century. Liverpool Schumacher Lectures, March 20. Berkeley, CA: Center for Ecoliteracy. Retrieved October 7, 2008, from http://www.ecoliteracy.org/pdf/challenge.pdf

Corcoran, P. B. (2004). What if? The educational possibilities of the Earth Charter. Educational Studies, 36(1), 108-117.

Ferrer-Balas, D., Adachi, J., Banas, S., Davidson, C. I., Hoshikoshi, A., Mishra, A., et al. (2008). An international comparative analysis of sustainability transformation across seven universities. International Journal of Sustainability in Higher Education, 9(3), 295-316. 
Filho, W. L. (1999). Sustainability and university life: Some European perspectives. In W. L. Filho (Ed.), Sustainability and university life (pp. 19-30). New York: Peter Lang.

Fischer, F. (2003). Reframing public policy: Discursive politics and deliberative practices. Oxford: Oxford University Press.

Freire, P. (2003). Pedagogy of the oppressed (M. B. Ramos, Trans.). New York: Continuum.

Furman, G. C., \& Gruenwald, D. A. (2004). Expanding the landscape of social justice: A critical ecological analysis. Educational Administration Quarterly, 40(1), 47-76.

Laforest, R., \& Phillips, S. (2007). Citizen engagement: Rewiring the policy process. In M. Orsini \& M. Smith (Eds.), Critical policy studies (pp. 67-90). Vancouver: UBC Press.

Margolis, E. (2001). The hidden curriculum in higher education. New York: Routledge.

McLean, M. (2006). Pedagogy and the university: Critical theory and practice. London, New York: Continuum.

Miller, J. P. (1988). The holistic curriculum. Toronto: OISE Press.

Moore, J. (2005a). Barriers and pathways to creating sustainability education programs: Policy, rhetoric and reality. Environmental Education Research, 11(5), 537-555.

Moore, J. (2005b). Policy, priorities and action: A case study of the University of British Columbia's engagement with sustainability. Higher Education Policy, 18(2), 179-197.

Orsini, M., \& Smith, M. (2007). Critical policy studies. Vancouver: UBC Press.

Raskin, P., Banuri, T., Gallopin, G., Gutman, P., Hammond, A., Kates, R., et al. (2002). Great transition: The promise and lure of the times ahead. Boston: Stockholm Environment Institute.

Robinson, J. (2009). Re: Development of the UBC Sustainability Academic Strategy. Retrieved October 7, 2008, from http://www.sas.ubc.ca/mandate/letter/

Scott, D. (2000). Reading educational research and policy. New York: Routledge.

Strange, C., \& Banning, J. (2001). Educating by design: Creating campus learning environments that work. San Francisco: Jossey-Bass.

Sustainable Endowments Institute. (2008). Sustainability report card 2009, Overall college sustainability leaders. Retrieved October 7, 2008, from http:// www.greenreportcard.org/report-card-2009/awards 
Tappeiner, G., Tappeiner, U., \& Walde, J. (2007). Integrating disciplinary research into an interdisciplinary framework: A case study in sustainability research. Environmental Modeling \& Assessment, 12(4), 253-256.

Taylor, S. (1997). Critical policy analysis: Exploring contexts, texts and consequences. Discourse: Studies in the Cultural Politics of Education, 18(1), 23-35.

Temple, P. (2008). Learning spaces in higher education: An under-researched topic. London Review of Education, 6(3), 229-241.

UBC, Office of the President. (2005). Trek 2010: A global journey. Vancouver: University of British Columbia, Office of the President.

UBC Sustainability Office. (2006). Inspirations and aspirations: The sustainability strategy. Vancouver: University of British Columbia, UBC Sustainability Office.

Wright, S. A. T. (2002). Definitions and frameworks for environmental sustainability in higher education. International Journal of Sustainability in Higher Education, 3(3), 203-220.

\section{CONTACT INFORMATION}

Nora Timmerman

Department of Educational Studies

University of British Columbia

2125 Main Mall

Vancouver, BC V6T 1Z4

Canada

norat@interchange.ubc.ca

Nora Timmerman is a doctoral student in the Department of Educational Studies at the University of British Columbia. She is interested in the complex interactions between ecological justice, epistemological understandings, and education, and her research focuses on the use of holistic pedagogy to transform and create understandings of knowledge that are compatible with an ecological justice paradigm.

Amy Scott Metcalfe is an assistant professor of Higher Education in the Department of Educational Studies at the University of British Columbia. Her research focuses on research policy studies, which includes aspects of academic labour, graduate student training, intellectual property, knowledge management, science studies, and academic capitalism. 